\title{
SUSPENSION LARGE SPAN ROOFS STRUCTURES IN RUSSIA
}

\author{
Pavel G. Eremeev, Ivan I. Vedyakov, Andrey I. Zvezdov \\ JSC Research Center of Construction
}

\begin{abstract}
Considered are large-span structures with suspended roof structures with a span of up to $200 \mathrm{~m}$, erected in Russia over the past 40 years. Among them, there are different types of structures for covering sports facilities: cablestayed systems, structures of the "bicycle wheel" type, combined systems, thin-sheet metal hanging shells, etc. The main technical characteristics of structures, principles of operation of structures, their advantages and disadvantages are given. The development of technologies in recent decades has determined the emergence of new forms, materials, design and construction methods. Unique large-span structures have an increased level of responsibility; their collapse can lead to severe economic and social consequences. In this regard, it is relevant to analyze the experience in the design and construction of large-span suspended structures.
\end{abstract}

Keywords: hanging large-span coatings in Russia, cable-stayed systems, structures of the "bicycle wheel" type, thinsheet metal hanging shells, scientific and technical support

\section{ВИСЯЧИЕ БОЛЫШЕПРОЛЕТНЫЕ КОНСТРУКЦИИ ПОКРЫТИЙ В РОССИИ}

\author{
П.Г. Еремеев, И.И. Ведяков, А.И. Звездов \\ АО «НИЦ «Строительство»
}

\begin{abstract}
Аннотация: Рассмотрены большепролетные сооружения с висячими конструкциями покрытий пролетом до 200 м, возведенных в России за последние 40 лет. В их числе, разные типы конструкций покрытий спортивных сооружений: вантовые системы, конструкции типа «велосипедное колесо», комбинированные системы, тонколистовые металлические висячие оболочки и т.д. Даны основные технические характеристики сооружений, принципы работы конструкций, их преимущества и недостатки. Развитие технологий в последние десятилетия определило появление новых форм, материалов, методов проектирования и строительства. Уникальные большепролетные сооружения имеют повышенный уровень ответственности, их обрушение может привести к тяжелым экономическим и социальным последствиям. В этой связи, актуальным является анализ опыта проектирования и возведения большепролетных висячих конструкций.
\end{abstract}

Ключевые слова: висячие большепролетные покрытия в России, вантовые системы, конструкции типа «велосипедное колесо», тонколистовые металлические висячие оболочки, научно-техническое сопровождение

\section{INTRODUCTION}

Hanging systems for covering structures were first proposed by the outstanding Russian engineer and scientist V.G. Shukhov. In 1896, at the All-Russian Exhibition in Nizhny Novgorod, he designed and built four pavilions (two - in plan dimensions 30 $\times 70 \mathrm{~m}$, one $50 \times 100 \mathrm{~m}$ and one round $-68 \mathrm{~m}$ in diameter) with hanging roofs with a total area of more than $10,000 \mathrm{~m}^{2}$. The cover was made of thin crisscrossing steel rods and strips (Fig. 1). A pavilion $25 \mathrm{~m}$ in diameter, round in plan, was covered with a hanging shell made of riveted iron sheets $1.6 \mathrm{~mm}$ thick (Fig. 2). This was another step forward: from trusses with purlins to openwork mesh, and from it to a continuous thin sheet, which was used for the first time in the world and for many years was the only case of such a coating. 


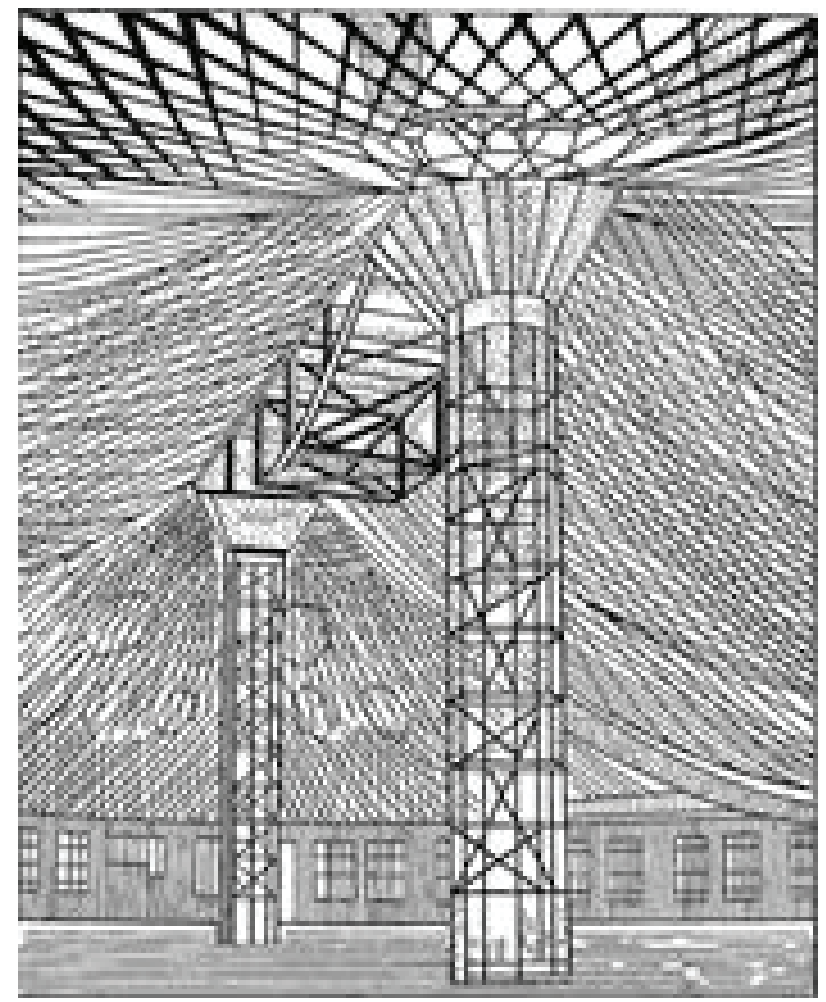

Figure 1. Hanging covering of the pavilion of the All-Russian Exhibition in N. Novgorod (1896).

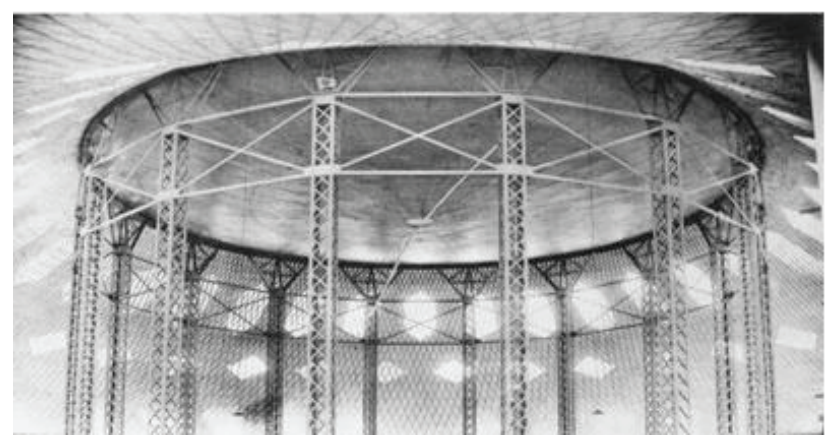

Figure 2. Membrane coating of the central part of the engineering and construction pavilion in N. Novgorod.

\section{RESULTS}

JSC "Research Center" Construction" developed new technical solutions, confirmed by copyright certificates and patents, carried out numerical and experimental studies of numerous hanging roofs of large-span structures. JSC "Research Center" Construction " took part in the design, provided scientific and technical support for their manufacture and installation. Below is a summary of the most interesting objects.

The most effective types of spatial structures of coatings include hanging shells made of a thin metal sheet stretched in two directions, combining bearing and enclosing functions in one material. Even in the case when a conventional roof is used, they do not require purlins, panels and other intermediate elements that are not involved in the spatial operation of the system $[4,5,6]$.

The use of such structures allows: to reduce the consumption of materials; reduce the time, labor intensity and cost of construction; reduce the cost of underlying structures (columns, foundations) by reducing the weight of the coating; minimize transportation costs.

A thin-sheet (up to $6 \mathrm{~mm}$ ) shell can cover structures with a span of more than $300 \mathrm{~m}$ with a plan outline from the simplest geometric shapes (square, rectangle, triangle, circle, oval, etc.) to a more complex combined outline. Thin-sheeted shells can have various surface shapes - cylindrical, spherical, hip-shaped, saddle-shaped, compound in the form of a combination of shells with the same or different surface shape. They are easy to manufacture and install, and have a minimum headroom. Thin-sheet panels with a width of up to $12 \mathrm{~m}$ and a span length are manufactured at the factory and delivered to the construction site rolled up. The tensile forces from the span structure are absorbed by the compressed-curved support contour, which works in conjunction with the membrane, which ensures its stability. The rational perception of these forces by the contour is one of the main tasks of designing thin-sheet pavements. This task is solved by the correct choice and mutual alignment of the surface shape and the outline of the coverage plan. Due to the lightness and low bending stiffness of the membranes, the problem arises of reducing their deformability. Stabilization of the coating can be provided in different ways: by its own weight, ballast weight, suspension of technological equipment; the introduction of the coating of reinforcing ribs with bending stiffness; prestressing the membrane. Experimental and theoretical studies of membrane shells were 
carried out, field surveys and monitoring of the erected structures were carried out, operating experience was generalized, recommendations for design and installation were developed. A number of structures with membrane coverings have been erected and are being successfully operated.

Indoor multifunctional stadium "Olympic" (Moscow, 1980). An oval building with plan dimensions of $224 \times 183 \mathrm{~m}$, covered with a $5 \mathrm{~mm}$ thick membrane shell (Fig. 3). The membrane is reinforced with a radial-ring system, which ensured the installation of the shell; during operation, it is used to fasten various technological equipment. The support contour with a section of $5 \times 1.75 \mathrm{~m}$ is made of monolithic reinforced concrete in a metal formwork. The membrane is designed to withstand a load of $10 \mathrm{kPa}$ in the center and $3.5 \mathrm{kPa}$ at the periphery.

Cycling track "Krylatskoe" (Moscow, 1980) dimensions in plan $168 \times 138 \mathrm{~m}$, shape close to an ellipse. The membrane covering $4 \mathrm{~mm}$ thick is

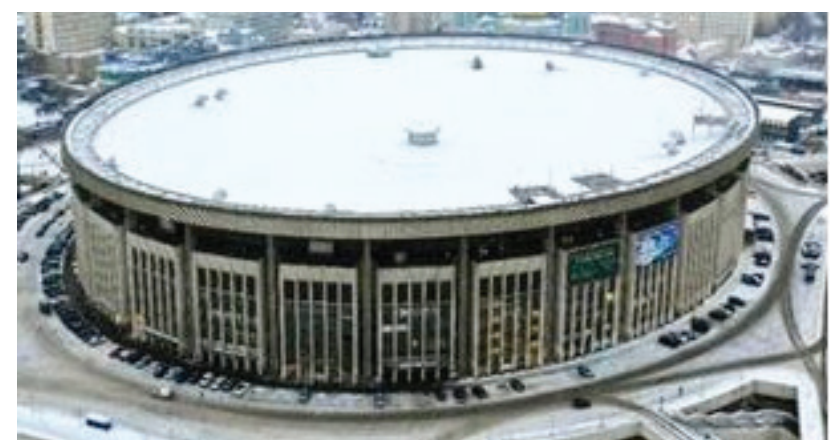

Figure 3. Indoor stadium of the sports complex "Olympic" in Moscow.

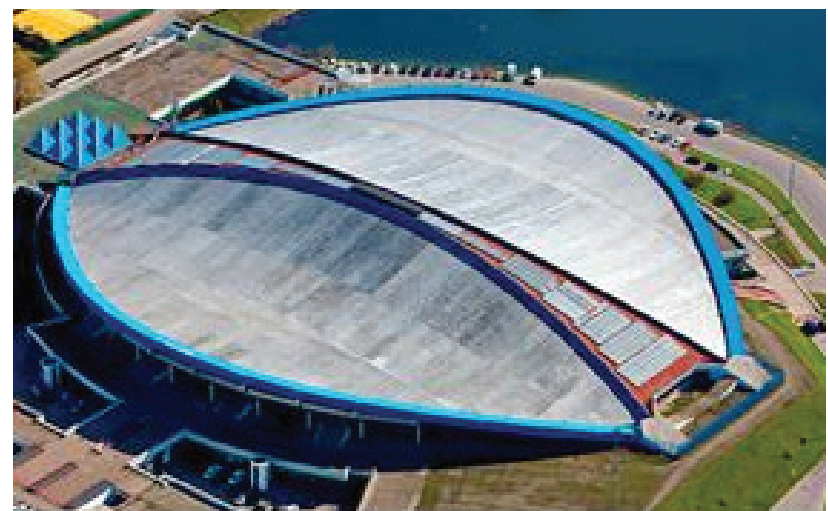

Figure 4. Cycling track in Krylatskoye in Moscow. made in the form of two saddle-shaped thin-sheet shells (Fig. 4), fixed on the arches with a span of $168 \mathrm{~m}$. Internal arches do not have intermediate supports and are combined into a spatial block. The outer arches in the middle part of the span are supported by the consoles of the stands. Arches steel box-section with dimensions of $3 \times 2 \mathrm{~m}$.

The universal sports complex "Izmailovo" (Moscow, 1980) consists of several volumes - the main hall measuring $66 \times 72 \mathrm{~m}$ and two training halls $-36 \times 36 \mathrm{~m}$, each of which is covered with a $2 \mathrm{~mm}$ thick stainless-steel membrane (Fig. 5). The supporting contour with a section of $0.5 \times 6.0 \mathrm{~m}$ is made of precast-monolithic reinforced concrete. The membrane was assembled by welding at ground level, from panels with a width of $9 \div 12$ $\mathrm{m}$, pre-enlarged at the factory from rolled tapes. The finished membrane was lifted by winches along the corner columns to the design position. For more than 35 years, the monitoring of structures has been carried out at all Olympic

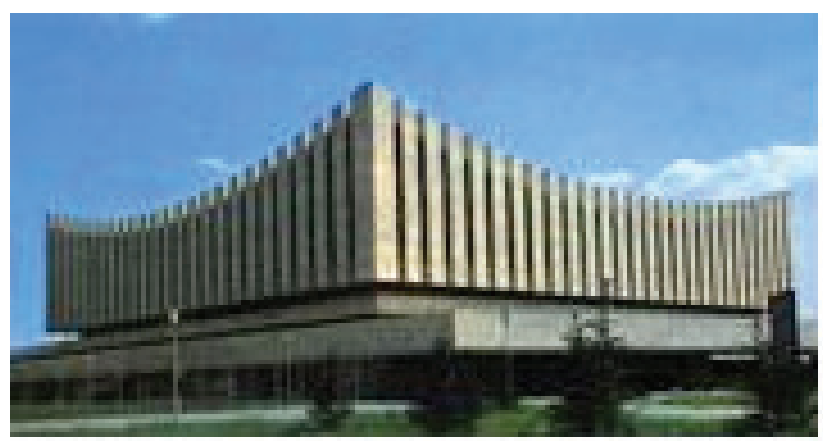

Figure 5. Sports hall "Izmailovo" in Moscow.

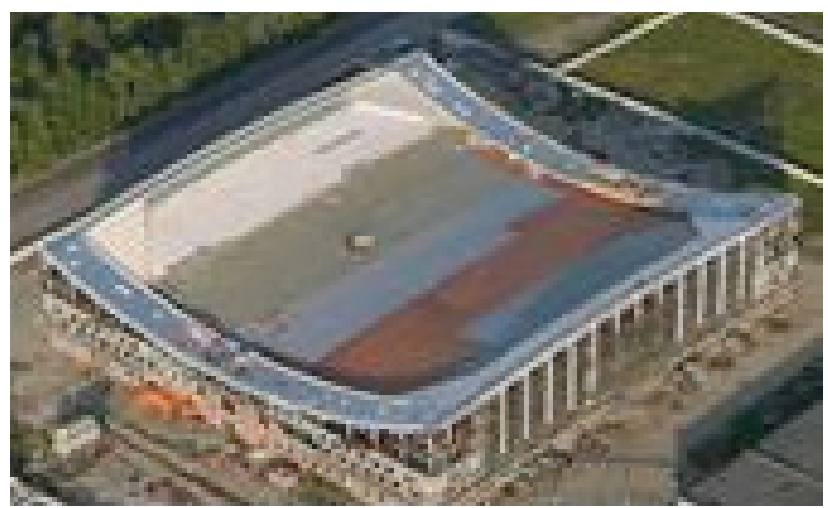

Figure 6. Ice Sports Palace in Angarsk. 
facilities, ensuring their reliability, timely repair work, and making informed decisions on extending the period of trouble-free operation of facilities. The membrane covering of the Ice Sports Palace (Angarsk, 2010) is made in the form of a cylindrical shell with dimensions in plan $90 \times 87$ m (Fig. 6). The closed support contour made of monolithic reinforced concrete consists of two rectilinear and two curved side elements. In the corners, the contour is reinforced with spacers.

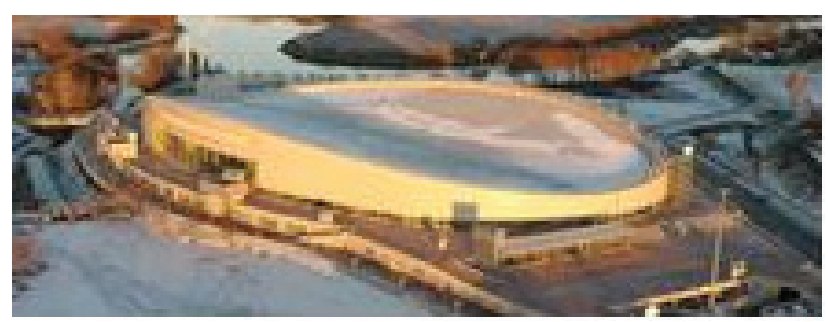

Figure 7. Speed skating center in Kolomna (Moscow region).

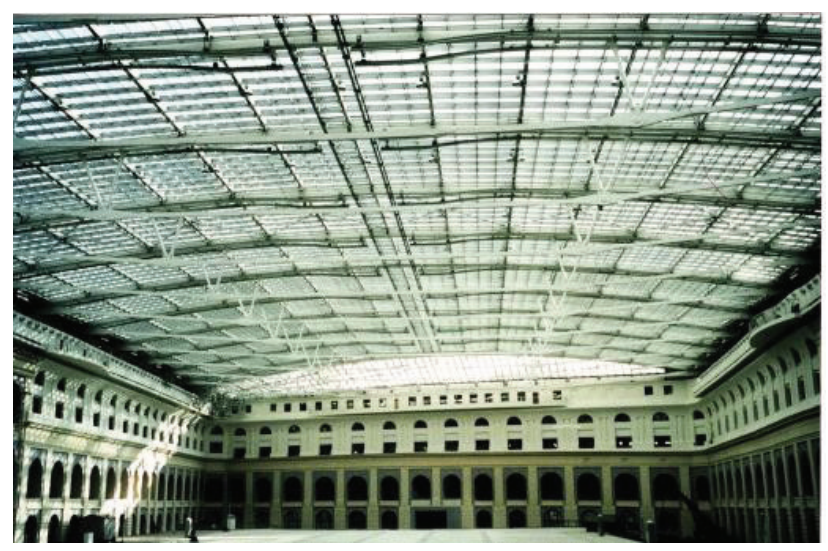

Figure 8. Old Gostiny Dvor in Moscow.

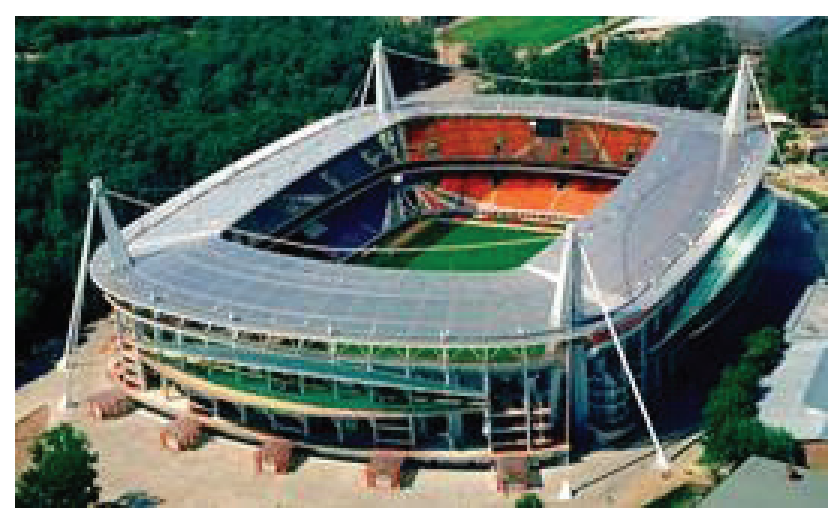

Figure 9. Stadium "Lokomotiv" in Moscow
Indoor speed skating center (Moscow region, 2006), has an oval plan with dimensions of $200 \times 110 \mathrm{~m}$. The cover is designed in the form of a saddle membrane shell $4 \mathrm{~mm}$ thick (Fig. 7). The supporting contour of a rectangular section $1.2 \times 2$ $\mathrm{m}$ is made in the form of a steel box filled with concrete. The contour along the long sides' rests on two arches with a span of about $75 \mathrm{~m}$, and in the rest of the sections on articulated posts with a pitch of about $12 \mathrm{~m}$.

The overlaps of a number of structures are made in the form of combined spatial structures, which include stretched elements and elements working in compression and bending [7, 8, 9, 10, 11]. In combined systems, the design length of compressed-bent elements is reduced, stretched elements made of high-strength metal are rationally used, and the structure's performance for uneven loads is improved. There are many types of combined systems, even the simplest of them are distinguished by great freedom in choosing the design scheme, materials used, manufacturing and installation methods. Elementary circuits are combined in a variety of ways into complex spatial structures.

The building of the "Old Gostiny Dvor" (Moscow, 1998) [12] has the shape of an irregular trapezoid in plan. The courtyard with side dimensions of 56 , 187,84 and $163 \mathrm{~m}$, with an area of $1500 \mathrm{~m}^{2}$, is covered with a translucent glass shell (Fig. 8). The load-bearing combined structures of the coating form a cylindrical surface. They consist of a convex, compressed-curved upper chord made of I-beams, a stretched lower chord made of steel strips, and two V-shaped struts connecting the chords. The football stadium "Lokomotiv-RZD Arena" (Moscow, 2001) was built oval in plan $(205.7 \times 157.3 \mathrm{~m})$ for 29 thousand spectators (Fig. 9). The roof over the stands (canopy outreach 33 $\mathrm{m}$ ) is suspended from four cable-stayed trusses. In the corners of the pavement, reinforced concrete pylons (about $50 \mathrm{~m}$ high) are installed, at the top of which there are hanging cables of two ropes (diameter $140 \mathrm{~mm}$ ). To them are attached in pairs inclined cables with a diameter of $50 \mathrm{~mm}$, to which the visor is suspended [13]. 
Ice Sports Palace (Moscow, 2005) - a building in the form of a cylinder with a diameter of $100 \mathrm{~m}$ and a height of $50 \mathrm{~m}$ (Fig. 10). The hanging mesh shell consists of an outer support contour, an inner ring, and a radial-annular system of flexurally rigid threads with diagonal ties.

Indoor speed skating center (Moscow, 2003). The construction plan is a segment of a circle with a radius of $117 \mathrm{~m}$ with a central angle of $\sim 160^{\circ}$ (Fig. 11).

The covering is formed by the same type of timber-metal trusses. A system of radial trusses (two spans $50.4 \mathrm{~m}$ each), with an annular beam in the middle of the covering, is suspended from 19 cables, which transmit the force to the foundation through a pylon (height $50 \mathrm{~m}$ ) and two guys reinforcing it [3].

The Volgograd Arena is a round structure with a diameter of $290.0 \mathrm{~m}$ with a coating consisting of two parts: above the stands and above the foyer (Fig. 12). The covering over the stands (oval $243.8 \times 206.7 \mathrm{~m}$, with an opening above the playing area $123.0 \times 85.9 \mathrm{~m}$ ) is a "bicycle wheel" type system with one compressed outer contour and

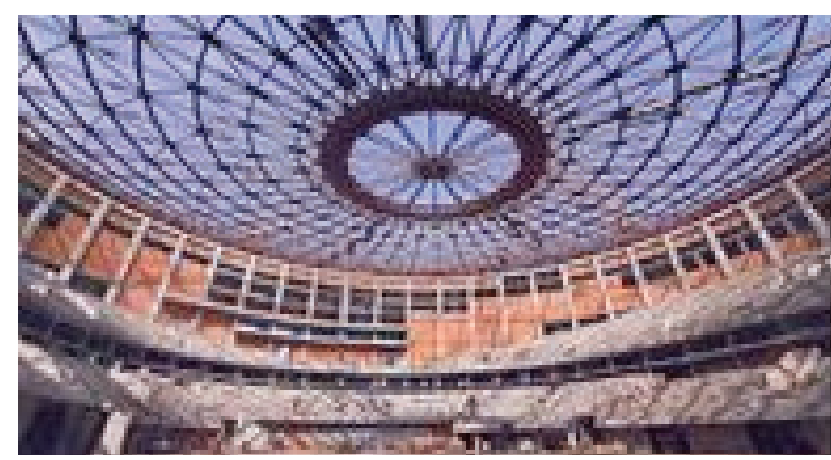

Figure 10. Ice Sports Palace.

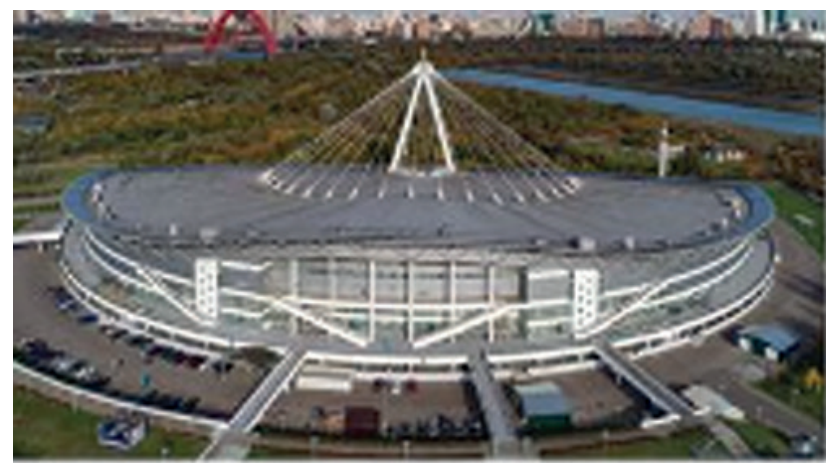

Figure 11. Indoor speed skating center. two stretched inner contours (from a package of cables) connected by radial cable-stayed trusses. Football stadium in Nizhny Novgorod. The pavement of the round structure with a diameter of $290.0 \mathrm{~m}$ consists of two parts: the pavement above the stands and the pavement above the foyer (Fig. 13). The covering above the stands (oval $240.3 \times 201.8 \mathrm{~m}$, with an opening above the playing area $123.0 \times 85.9 \mathrm{~m}$ ) is a radial-circular rod shell of the "bicycle wheel" type, with loadbearing elements made of welded I-beams. "Rostov Arena" (Fig. 14) with an oval-shaped surface measuring $257.2 \times 218.5 .0 \mathrm{~m}$ with a rectangular cutout $(130.5 \times 91.8 \mathrm{~m})$ above the football field. The main supporting structures are a system of radial cantilever beams with an outreach of $51.34 \mathrm{~m}$, united by circular girders and ties. The cantilever beams are attached by two inclined cable-stayed suspensions to the top of the pylons located along the perimeter of the stadium, the forces from which are absorbed by the braces, which are locked onto the grillages. Kaliningrad Stadium (Fig. 15). The structure in plan has the shape of a rectangle measuring $166.7 \times 203.7 \mathrm{~m}$ with rounded corners with a

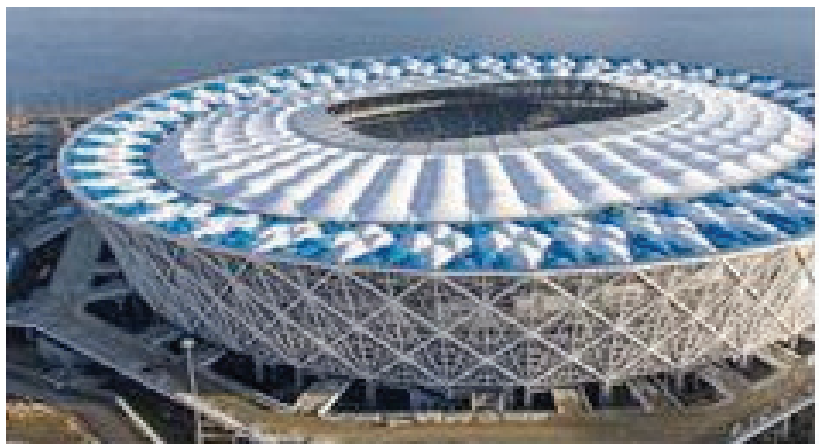

Figure 12. "Volgograd Arena".

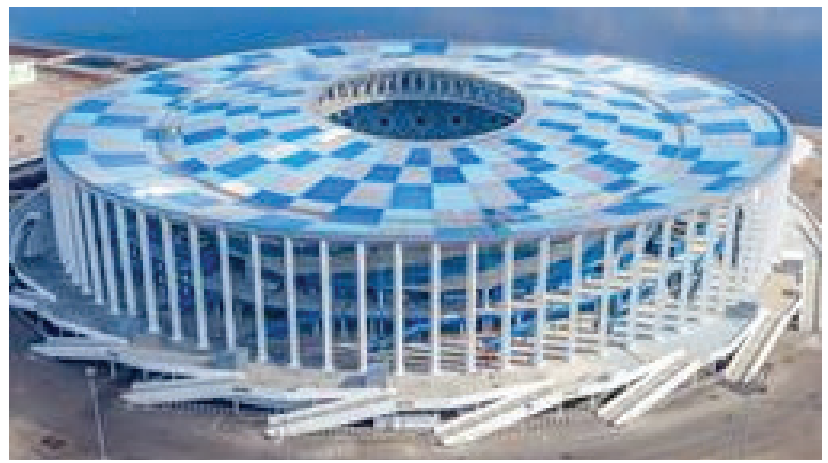

Figure 13. Stadium in Nizhny Novgorod. 
rectangular opening above the football field. The bearing structures of the pavement are a spatial core system that includes radial and ring trusses, united by ties. All main bar elements are designed from steel box sections. Cantilever radial trusses with an outreach of $38.2 \mathrm{~m}$ are suspended from the top of the pylons located along the perimeter of the stadium, the efforts from which are absorbed by the braces, which are closed on the frame of the stands. Football stadium in Krasnodar. The covering above the stadium stands is a cable-stayed system, such as a "bicycle wheel" with two compressed steel outer contours and a stretched inner ring in the form of a set of cables connected by a system of radial cable-stayed trusses (Fig. 16).

The VTB-Arena stadium in Moscow has an oval shape in plan. The maximum dimensions are $300 \times 187 \mathrm{~m}$, the height of the structure is $66 \mathrm{~m}$ (Fig. 17). There is also a covered arena under the shell. The shell itself is made in the form of a spatial rod system, reinforced with trusses in the coverage area above the stands.

JSC "Research Center" Construction" took part in the design of the above objects, provided scientific and technical support for their manufacture and installation, which included $[1,2]$ :

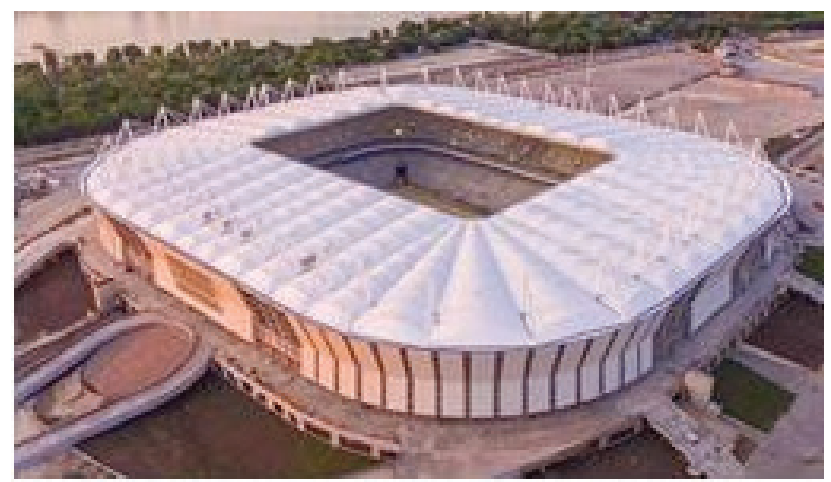

Figure 14. Rostov Arena.

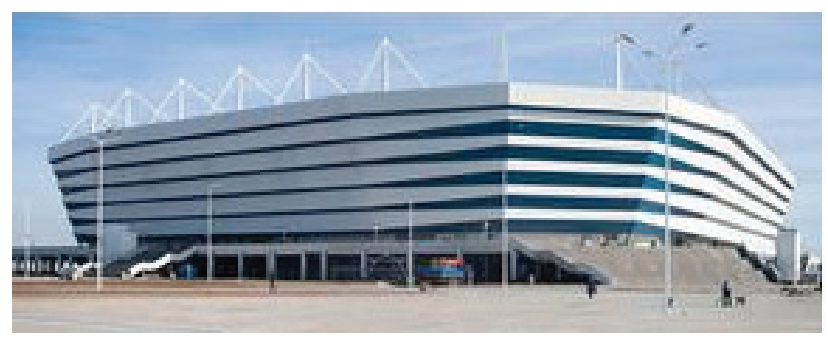

Figure 15. Kaliningrad Stadium.
- theoretical numerical research;

- testing of large-scale models in order to identify the actual operation of various systems, check the initial assumptions and conclusions of theoretical studies;

- carrying out field surveys and generalization of operating experience;

- development of practical recommendations for the calculation and design of large-span metal structures, taking into account the issues of their manufacture and installation.

These studies allowed solving numerous problems associated with identifying the actual operation of structures, additional reserves for increasing their efficiency and reliability. Based on the generalization of the experience of research, design, construction and operation of large-span spatial structures, a number of recommendations have been developed.

\section{CONCLUSION}

1. Hanging large-span structures have an increased level of responsibility, their failures can lead to severe economic and social consequences. In

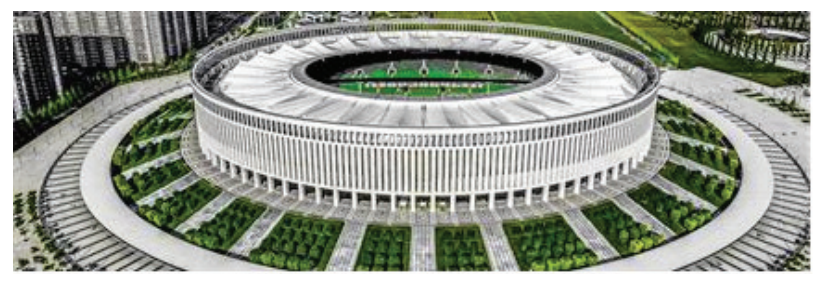

Figure 16. Stadium in Krasnodar.

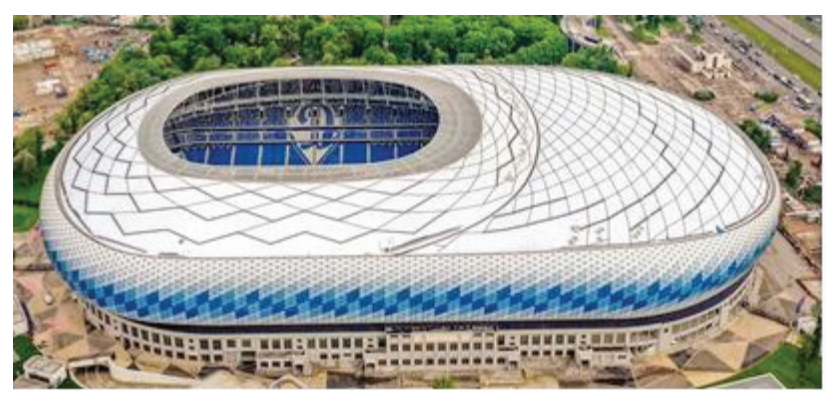

Figure 17. VTB-Arena. 
this regard, additional requirements should be taken into account for the nomenclature and scope of surveys and design work, the manufacture and installation of structures, the rules for their acceptance and operation.

2. Design should be based on the choice of rational design solutions linked to the functional purpose, architecture, manufacturing and installation methods, operating conditions, the ideas put forward should be technically and economically justified.

3. When designing, problems arise that go beyond the normative documents, which require special knowledge and practical experience from the engineer. An important feature of the process is the generation of ideas based on the creativity of the designer.

4. To increase the reliability of the results, verification calculations should be carried out using various modern certified software systems. It should be borne in mind that using a computer has a downside, the risk of errors increases. A clear understanding of how the structure works, based on the rules of structural mechanics, is required.

5. Ensuring high reliability of hanging largespan structures requires mandatory scientific and technical support, which usually includes:

- development of recommendations for determining snow and wind loads based on the results of blowing a model of a structure in a specialized wind tunnel. Climatic loads are taken taking into account the service life of the structure; - performing verification calculations;

- carrying out, in some cases, experimental studies of large-scale physical models and fullscale assemblies to assess the bearing capacity and reliability of structures; verification of the calculation model and calculation methods;

- development of "Specifications for the manufacture and installation of structures" with additional requirements that are not included in the current regulatory and technical documents.

- Carrying out technical monitoring at the stage of construction and the first years of operation.

\section{REFERENCES}

1. Vedyakov I.I., Yeremeyev P.G., Solov'yev D.V. Nauchno-tekhnicheskoye soprovozhdeniye i normativnyye trebovaniya pri realizatsii proyektov zdaniy i sooruzheniy povyshennogo urovnya otvetstvennosti [Scientific and technical support and regulatory requirements in the implementation of projects of buildings and structures with a higher level of responsibility] // Promyshlennoye i grazhdanskoye stroitel'stvo. 2018. No 12, Pp. 4-9.

2. Yeremeyev P.G., Vedyakov I.I. Monitoring i ekspluatatsiya metallicheskikh konstruktsiy unikal'nykh bol'sheproletnykh sooruzheniy [Monitoring and operation of metal structures for unique large-span structures] // Stroitel'nyye materialy, oborudovaniye, tekhnologii XXI. No 5-6, Pp. 46-48.

3. Yeremeyev P.G., Vedyakov I.I. Proyektirovaniye i vozvedeniye metallicheskikh konstruktsiy bol'sheproletnykh zdaniy i sooruzheniy [Design and construction of metal structures for large-span buildings and structures] // Stroitel'nyye materialy. 2017. No 4. Pp. 55-58

4. Yeremeyev P.G. Prostranstvennyye tonkolistovyye metallicheskiye konstruktsii pokrytiy [Spatial thin-sheet metal structures of coatings]. Moscow: Publishing ASV, 2006. $560 \mathrm{p}$.

5. Yeremeyev P.G. Sovremennyye stal'nyye konstruktsii bol'sheproletnykh pokrytiy unikal'nykh zdaniy i sooruzheniy [Modern steel structures of large-span roofs of unique buildings and structures]. Moscow: Publishing ASV, 2009. 336 p.

6. Yeremeyev P.G. Prostranstvennyye metallicheskiye konstruktsii pokrytiy [Spatial metal structures of coatings]. Moscow: Publishing ASV, 2020. - 508 p.

7. Gonzalez Quelle I. Cable Roofs. Evolution, Classification and Future Trends. Proceedings of the IASS Symposium. Valencia, Spain, 2009. - pp. 264-276. 
8. Lewis W. Tension structures: Form and behavior. Thomas Telford, London. 2003. $201 \mathrm{p}$.

9. Santoso K. Wide-span cable structures. Massachusetts Institute of Technology. 2004. $-70 \mathrm{p}$.

10. Seidel M. Tensile Surface Structures: A Practical Guide to Cable and Membrane Construction. Wiley, 2009. - 240 p.

11. Schlaich J., Bergermann R., Leich Weit. Light Structures, (2nd ed.), Prestel, Munich, 2005. - $328 \mathrm{p}$.

12. Yeremeyev P., Kancheli N. Large-span transparent roof for "Gostiny Dvor" complex in Moscow. Proceedings of the IASS International Congress, Moscow, Russia, vol. II. 1998. Pp. 469-476.

13. Yeremeyev P., Kiselev D., Savelyev V. Steel Carrying Structure of the Roof over the Lokomotiv Moscow Stadium Stands. Proceeding of the Fifth International Conference on Space Structure, vol. 2. 2002. Pp. 1304-1312.

\section{СПИСОК ЛИТЕРАТУРЫ}

1. Ведяков И.И., Еремеев П.Г., Соловьев Д.В. Научно-техническое сопровождение и нормативные требования при реализации проектов зданий и сооружений повышенного уровня ответственности. Промышленное и гражданское строительство № 12, 2018. - C. 4-9.

2. Еремеев П.Г., Ведяков И.И. Мониторинг и эксплуатация металлических конструкций уникальных большепролетных сооружений. Строительные материалы, оборудование, технологии XXI ВЕКА №5-6, 2017. - C. 46-48.

3. Еремеев П.Г., Ведяков И.И. Проектирование и возведение металлических конструкций большепролетных зданий и сооружений. Строительные материалы №4. - 2017. - С. 55-58.

4. Еремеев П.Г. Пространственные тонколистовые металлические конструкции покрытий. М.: Издательство АСВ, 2006. 560 c.

5. Еремеев П.Г. Современные стальные конструкции большепролетных покрытий уникальных зданий и сооружений. М.: Издательство АСВ, 2009. 336 с.

6. Еремеев П.Г. Пространственные металлические конструкции покрытий. М.: Издательство Ассоциации строительных вузов, 2020. - 508 c.

7. Gonzalez Quelle I. Cable Roofs. Evolution, Classification and Future Trends. Proceedings of the IASS Symposium. Valencia, Spain, 2009. - pp. 264-276.

8. Lewis W. Tension structures: Form and behavior. Thomas Telford, London. 2003. $201 \mathrm{p}$.

9. Santoso K. Wide-span cable structures. Massachusetts Institute of Technology. 2004. $-70 \mathrm{p}$.

10. Seidel M. Tensile Surface Structures: A Practical Guide to Cable and Membrane Construction. Wiley, 2009. - $240 \mathrm{p}$.

11. Schlaich J., Bergermann R., Leich Weit. Light Structures, (2nd ed.), Prestel, Munich, 2005. - 328 p.

12. Yeremeyev P., Kancheli N. Large-span transparent roof for "Gostiny Dvor" complex in Moscow. Proceedings of the IASS International Congress, Moscow, Russia, vol. II. 1998. - Pp. 469-476.

13. Yeremeyev P., Kiselev D., Savelyev V. Steel Carrying Structure of the Roof over the Lokomotiv Moscow Stadium Stands. Proceeding of the Fifth International Conference on Space Structure, vol. 2. 2002. - Pp. 1304-1312. 
Pavel G. Eremeev, Dr.Sc.; Professor, Head Researcher, Laboratories of metal constructions, The Central Research and Experimental Design Institute of Civil Engineering (TsNIISK) named after V.A. Kucherenko, JSC Research Center of Construction; 109428, Moscow, Russia, 2-nd Institutskaya str., 6; phone: +7(499) 174-7325; Email: eremeevpg@rambler.ru.

Ivan I. Vedyakov, Dr.Sc.; Professor, Director The Central Research and Experimental Design Institute of Civil Engineering (TsNIISK) named after V.A. Kucherenko, JSC Research Center of Construction; 109428, Moscow, Russia, 2-nd Institutskaya str., 6; tel. +7(499) 171-92-65; Email: vedyakov@tsniisk.ru

Andrey I. Zvezdov, Dr.Sc.; Professor, Deputy General Director for Science, JSC Research Center of Construction; 109428, Moscow, Russia, 2-nd Institutskaya str., 6; tel. +7(495) 602-00-70, Email: zvezdov@cstroy.ru
Еремеев Павел Георгиевич, доктор технических наук; профессор, главный научный сотрудник лаборатории металлических конструкций, ЦНИИСК им. В.А. Кучеренко, «НИЦ «Строительство»; 109428, Россия, г. Москва, 2-я Институтская улица, дом 6; телефон: +7(499) 174-73-25; Email: eremeevpg@rambler.ru.

Ведяков Иван Иванович, доктор технических наук; профессор, директор ЦНИИСК им. В.А. Кучеренко, «НИЦ «Строительство»; 109428, Россия, г. Москва, 2-я Институтская улица, дом 6; телефон: +7(499) 171-92-65; Email: vedyakov@tsniisk.ru

Андрей Иванович Звездов, Заместитель генерального директора по науке, «НИЦ «Строительство»; 109428, Россия, г. Москва, 2-я Институтская улица, дом 6; телефон: +7(495) 602-00-70, Email: zvezdov@cstroy.ru 